\title{
Pengaruh Motivasi Belajar dan Perhatian Orangtua Terhadap Hasil Belajar Matematika Siswa Kelas VII SMP Negeri 1 Baso Tahun Pelajaran 2018/2019
}

\author{
Silvi Junita ${ }^{1}$, Alfi Rahmi, M.Pd ${ }^{2}$, dan Haida Fitri, M.Si ${ }^{3}$ \\ 1,2,3 Program Studi Pendidikan Matematika, FTIK Institut Agama Islam Negeri Bukittinggi \\ Email: silfijunita01@gmail.com
}

\begin{abstract}
ABSTRAK. Penelitian ini bertujuan untuk mengetahui untuk mengetahui pengaruh signifikan motivasi belajar terhadap hasil belajar matematika siswa, pengaruh signifikan perhatian orangtua terhadap hasil belajar matematika siswa, dan pengaruh signifikan motivasi dan perhatian orangtua secara simultan terhadap hasil belajar matematika siswa di kelas VII SMP Negeri 1 Baso tahun pelajaran 2018/2019. Jenis penelitian yang digunakan adalah expost facto. Populasi dalam penelitian ini adalah siswa kelas VII SMP Negeri 1 Baso Tahun Pelajaran 2018/2019. Sampel penelitian sebanyak 31 orang siswa kelas VII yang dipilah secara random sampling. Instrumen yang digunakan untuk pengambilan data adalah instrumen angket motivasi belajar yang terdiri dari 45 item pernyataan dan instrumen perhatian orangtua yang terdiri dari 38 item pernyataan dan hasil belajar metematika siswa diperoleh dari guru Matematika SMP Negeri 1 Baso. Hasil penelitian menunjukkan bahwa secara parsial motivasi belajar terhadap hasil belajar matematika siswa denagan sumbangan sebesar 20,307\%, perhatian orangtua terhadap hasil belajar matematika dengan sumbangan sebesar $16,3406 \%$, dan motivasi belajar dan perhatian orangtua secara simultan memberikan pengaruh yang signifikan terhadap hasil belajar matematika siswa kelas VII SMP Neger 1 Baso Tahun Pelajaran 2018/2019 dengan sumbangan sebesar 25,2004\%.
\end{abstract}

Kata kunci: hasil belajar matematika, motivasi belajar, perhatian orangtua

\section{PENDAHULUAN}

Hasil belajar yang baik merupakan salah satu indikator kesuksesan dari sebuah proses belajar siswa di sekolah. Hasil belajar yang diperoleh oleh siswa tidak lepas dari proses belajar dan faktor-faktor yang mempengaruhi belajar. Suryabrata mengatakan faktor-faktor yang mempengaruhi belajar banyak jenisnya, dari beberapa jenis digolongkan menjadi dua golongan yaitu faktor internal dan faktor eksternal. Faktor internal adalah faktor yang ada dalam diri individu yang sedang belajar, sedangkan faktor eksternal adalah faktor yang ada diluar diri individu. Faktor internal terbagi menjadi faktor fisiologis (jasmani) dan faktor psikologis (minat, dan motivasi). Faktor ekternal terbagi menjadi faktor sosial (orangtua, guru, teman-teman atau lingkungan belajar) dan faktor non sosial (waktu, tempat, alat perlengkapan belajar dan sebagainya). Faktor-faktor yang mempengaruhi hasil belajar tersebut bersifat umum, tetapi juga berlaku sebagai faktor-faktor yang mempengaruhi hasil belajar matematika siswa.

Motivasi merupakan salah satu faktor yang mempengaruhi hasil belajar. Motivasi juga mempunyai arti yang sangat penting dalam kegiatan belajar. Karena adanya motivasi akan mendorong semangat belajar, dan sebaliknya kurang adanya motivasi akan melemahkan semangat belajar. Motivasi merupakan syarat mutlak dalam belajar, seorang siswa yang belajar tanpa motivasi atau kurang motivasi tidak akan berhasil dengan maksimal. 
Indikator motivasi belajar menurut Hamzah B Uno antara lain sebagai berikut:

a. Adanya hasrat dan keinginan berhasil.

b. Adanya dorongan dan kebutuhan dalam belajar.

c. Adanya harapan dan cita-cita masa depan.

d. Adanya penghargaan dalam belajar.

e. Adanya kegiatan yang menarik dalam belajar.

f. Adanya lingkungan belajar yang kondusif, sehingga memungkinkan seseorang siswa dapat belajar dengan baik.

Indikator motivasi belajar menurut Riduwan yaitu:

a. Ketekunan dalam belajar

1) Kehadiran di sekolah

2) Mengikuti PBM di kelas

3) Belajar di rumah

b. Ulet dalam menghadapi kesulitan

1) Sikap terhadap kesulitan

2) Usaha mengatasi kesulitan

c. Minat dan ketajaman perhatian dalam belajar

1) Kebiasaan dalam mengikuti pelajaran

2) Semangat dalam mengikuti PBM

d. Berprestasi dalam belajar

1) Keinginan untuk berprestasi

2) Kualifikasi hasil

e. Mandiri dalam belajar

1) Penyelesaian tugas/PR

2) Menggunakan kesempatan diluar jam pelajaran

Ada beberapa peranan penting motivasi dalam belajar dan pembelajaran antara lain: peran motivasi dalam menentukan penguatan belajar, peran motivasi dalam memperjelas tujuan belajar, dan motivasi menentukan ketekunan belajar. Kemudian motivasi belajar juga didasarkan pada adanya hasrat dan keinginan berhasil, adanya dorongan dan kebutuhan dalam belajar, adanya harapan dan cita-cita masa depan, adanya penghargaan dalam belajar, adanya kegiatan yang menarik dalam belajar, dan adanya lingkungan belajar yang kondusif, sehingga memungkinkan siswa dapat belajar dengan baik.

Selain motivasi, perhatian orangtua juga merupakan salah satu faktor yang akan mempengaruhi hasil belajar siswa. Orangtua berperan penting dalam hasil belajar anak di sekolah. Karena orangtua mempunyai peranan dan tanggung jawab utama atas perawatan dan perlindungan anak sejak bayi hingga remaja. Semua orangtua mempunyai tanggung jawab yang mulia untuk memberi pendidikan jasmani, rohani, dan pendidikan mental. Inilah yang menjadi tujuan setiap orangtua supaya memberikan jaminan dalam perkembangan pada anaknya. Mereka harus tumbuh dalam lingkungan keluarga dengan penuh kasih sayang dan perhatian. Perhatian orangtua dalam mendidik anak di lingkungan keluarga sangatlah penting, karena lingkungan keluarga adalah tempat terbaik untuk memulai pendidikan.

Keterlibatan orangtua dalam memberikan bimbingan belajar bagi anak dan juga menyidiakan fasilitas belajar terutama buku-buku pelajaran serta dorongan untuk lebih mengiatkan belajar. Sekolah dan rumah, dalam hal ini orangtua mempunyai hubungan yang erat. Hubungan yang positif dapat dipengaruhi oleh jaringan sosial orangtua. Jaringan sosial yang dimiliki orangtua dapat mempengaruhi sikap dan kepercayaan terhadap sekolah.

Perhatian orangtua memiliki indikator menurut Abdullah Nashih Ulwan yaitu:

a. Perhatian dari segi keimanan anak

b. Perhatian segi moral anak 
c. Perhatian segi mental dan intelegtual anak

d. Perhatian segi jasmani anak

e. Perhatian segi kejiwaan anak

f. Perhatian segi sosial anak

g. Perhatian segi spiritual anak

Indikator perhatian orangtua dalam jurnal Tri Sumiati antara lain:

a. Bimbingan belajar siswa yang dilakukan orangtua dirumah.

b. Siswa memperoleh motivasi belajar dari orangtua.

c. Keterlibatan orangtua dalam kegiatan belajar siswa.

d. Kondisi belajar siswa yang baik dirumah diciptakan orangtua.

e. Orangtua menyediakan fasilitas belajar yang lengkap.

Indikator perhatian orangtua dalam jurnal Rizka Iftikhah antara lain:

a. Perhatian orangtua dalam bentuk material

1) Perhatian terhadap uang saku dan sumbangan-sumbangan sekolah

2) Perhatian terhadap alat belajar

3) Perhatian terhadap tempat belajar

4) Perhatian terhadap biaya pendidikan

b. Perhatian orangtua dalam bentuk psikologi

1) Pemberian kasih sayang

2) Pemberian disiplin orangtua

3) Pemberian penghargaan

Orangtua berperan penting dalam prestasi anak di sekolah, karena orangtua mempunyai peranan dan tanggung jawab utama atas perawatan dan perlindungan anak sejak bayi hingga remaja. Semua orangtua mempunyai tanggung jawab yang mulia untuk memberikan pendidikan jasmani, rohani, dan pendidikan mental. Inilah yang menjadi tujuan setiap orangtua supaya memberikan jaminan dalam perkembangan pada anaknya. Perhatian orangtua dalam mendidik anak di lingkungan keluarga sangatlah penting, karena lingkungan keluarga adalah tempat terbaik untuk memulai pendidikan.

Peneliti mendapatkan data hasil ulangan tengah semester ganjil matematika siswa kelas VII SMP Negeri 1 Baso yang diperoleh sebagai berikut:

Tabel 1. Presentasi Nilai Ujian Tengah Semester Ganjil Matematika Kelas VII SMP Negeri 1 Baso Tahun Pelajaran 2018/2019

\begin{tabular}{|c|c|c|c|c|}
\hline \multirow[t]{2}{*}{ Kelas } & \multirow[t]{2}{*}{ Siswa } & \multirow[t]{2}{*}{ KKM } & \multicolumn{2}{|c|}{ Persentase Ketuntasan } \\
\hline & & & Tuntas & Tidak Tuntas \\
\hline $\mathrm{VII}_{1}$ & 33 & 65 & $42,42 \%$ & $57,57 \%$ \\
\hline $\mathrm{VII}_{2}$ & 31 & 65 & $19,35 \%$ & $80,64 \%$ \\
\hline $\mathrm{VII}_{3}$ & 30 & 65 & $40 \%$ & $60 \%$ \\
\hline $\mathrm{VII}_{4}$ & 30 & 65 & $26,66 \%$ & $73,33 \%$ \\
\hline
\end{tabular}

Sumber: guru mata pelajaran matematika kelas VII SMP Negeri 1 Baso

Berdasarkan tabel di atas dapat diketahui bahwa persentase ketuntasan nilai ujian tengah semster ganjil kelas VII SMP Negeri 1 Baso Tahun Pelajaran 2018/2019 pada mata pelajaran matematika di bawah 50\%.

Berdasarkan pemaparan diatas, maka dapat diasumsikan bahwa motivasi belajar dan perhatian orangtua adalah dua variabel yang dapat mempengaruhi hasil belajar matematika siswa.

\section{METODE}

Penelitian ini menggunakan jenis penelitian expost facto. Penelitian ini dilaksanakan pada bulan Desember 2018 di sekolah SMP Negeri 1 Baso. Populasi dalam penelitian ini adalah siswa kelas 
VII SMP Negeri 1 Baso tahun pelajaran 2018/2019 yang ber jumlah 124 orang siswa. Sampel yang digunakan sebanyak 31 orang siswa dipilih dengan tenik random sampling.

Instrumen yang digunakan dalam penelitian ini adalah angket motivasi belajar, angket perhatian orangtua dan hasil ujian matematika semester ganjil tahun pelajaran 2018/2019 yang diperoleh dari guru matematika SMP Negeri 1 Baso.

Validasi dalam penelitian ini dilakukan dengan validasi isi dan validasi empiris. Validasi isi dilakukan dengan meminta bantuan pada validator yaitu duan orang dosen Bimbingan dan Konseling dan guru Bahasa Indonesia, dan validasi empiris dilakukan pada siswa kelas VII SMP Negeri 1 Baso yaitu sebanyak 33 orang siswa yang mana siswa tersebut tidak merupakan sampel dari penelitian. Reliabelitas tes berhubungan dengan kepercayaan hasil tes. Suatu tes dapat dikatakan mempunyai tingkat kepercayaan yang tinggi jika tes tersebut dapat memberikan hasil yang tetap.

Untuk pengujian Hipotesis yang diajukan maka penelitian ini menggunakan analisis regresi sederhana (parsial) dan analisis regresi berganda (simultan). Model persamaan regresi parsial yaitu:

$Y=a+b \cdot X$

Keterangan:

$\mathrm{Y} \quad=$ variabel tak bebas (terikat)

$\mathrm{X} \quad=$ variabel bebas

$\mathrm{a}$ dan $\mathrm{b} \quad=$ konstanta

Dalam penelitian ini digunakan analisis regresi linier sederhana (parsial). Untuk itu perlu dilakukan pengujian prasyarat analisis yang berupa uji normalitas dan linieritas. Uji yang digunakan untuk regresi parsial adalah uji t dengan rumus sebagai berikut:

$t_{\text {hitung }}=\frac{r \sqrt{n-2}}{\sqrt{1-r^{2}}} \quad$ (Riduwan, 2013:138)

Model persaman regresi secara simultan yaitu:

$Y=a+b_{1} X_{1}+b_{2} X_{2}$

Keterangan:

$\mathrm{Y} \quad=$ variabel terikat

$X_{1} \quad=$ motivasi belajar

$X_{2} \quad=$ perhatian orangtua

$a, b_{1}, b_{2} \quad=$ konstanta

Analisi regresi linier berganda (simultan) yang digunakan dalam penelitian ini dilakukan uji prasyarat uji normalitas, uji linieritas, uji multikolinieritas, uji heterokedastisitas, dan autokorelasi.

Untuk regresi berganda uji yang digunakan adalah uji $\mathrm{F}$ dengan rumus sebagai berikut:

$F_{\text {hitung }}=\frac{\left(R_{X_{1}, X_{2}, Y}\right)^{2}(n-m-1)}{m\left(1-R_{X_{1}, X_{2}, Y}^{2}\right)}($ Sofyan Siregar, 2014:446)

Pada pengujian hipotesis akan dilihat apakah terdapat pengaruh signifikan secara simultan variabel bebas terhadap variabel terikat. 


\section{HASIL DAN PEMBAHASAN}

\section{Deskripsi Hasil Penelitian}

Gambaran mengenai varabel motivasi belajar, perhatian orangtua dan hasil belajar metematika dapat dilihat sebagai berikut:

Tabel 2. Kriteria Interpretasi Skor

\begin{tabular}{cc}
\hline Skala & Kriteria \\
\hline $\mathbf{0 \% - 2 0 \%}$ & Sangat lemah \\
$\mathbf{2 1 \%} \mathbf{- 4 0 \%}$ & Lemah \\
$\mathbf{4 1 \% - 6 0 \%}$ & Cukup \\
$\mathbf{6 1 \% - 8 0} \%$ & Kuat \\
$\mathbf{8 1 \% - 1 0 0 \%}$ & Sangat kuat \\
\hline
\end{tabular}

Variabel motivasi belajar

Tabel 3. Data Deskriptif Motivasi Bealajar Kelas VII SMP Negeri 1 Baso

Tahun Pelajaran 2018/2019

\begin{tabular}{ll}
\hline Data Deskripsi & Hasil \\
\hline Mean & 163,4194 \\
Median & 154 \\
Skor Minimum & 127 \\
Skor Maksimum & 205 \\
Jumlah Skor Keseluruhan & 5066 \\
\hline
\end{tabular}

Tabel 4. Distribusi Motivasi Belajar Siswa Kelas VII SMP Negeri 1 Baso

Tahun Pelajaran 2018/2019

\begin{tabular}{lcc}
\hline Interval & Frekuensi & Persentase \\
\hline $\mathbf{1 2 7 - 1 3 9}$ & 6 & $19,35 \%$ \\
$\mathbf{1 4 0 - 1 5 2}$ & 6 & $19,35 \%$ \\
$\mathbf{1 5 3 - 1 6 5}$ & 6 & $19,35 \%$ \\
$\mathbf{1 6 6 - 1 7 8}$ & - & $0 \%$ \\
$\mathbf{1 7 9 - 1 9 1}$ & 8 & $25,80 \%$ \\
$\mathbf{1 9 2 - 2 0 5}$ & 5 & $16,12 \%$ \\
\hline
\end{tabular}

Dari tabel 4 diatas motivasi belajar siswa sangat lemah sebanyak 23 orang siswa atau $19,35 \%$, lemah sebanyak 8 orang atau $25,80 \%$.

Variabel perhatian orangtua

Tabel 5. Data Deskriptif Perhatian Orangtua Kelas VII SMP Negeri 1 Baso

Tahun Pelajaran 2018/2019

\begin{tabular}{cc}
\hline Data Deskripsi & Hasil \\
\hline Mean & 127,4194 \\
Median & 127 \\
Skor Minimum & 99 \\
Skor Maksimum & 162 \\
Jumlah Skor Keseluruhan & 3950 \\
\hline
\end{tabular}

Tabel 6. Distribusi Perhatian Orangtua Siswa Kelas VII SMP Negeri 1 Baso

Tahun Pelajaran 2018/2019

\begin{tabular}{ccc}
\hline Interval & Frekuensi & Persentase \\
\hline $\mathbf{9 9 - 1 0 9}$ & 7 & $22,58 \%$ \\
$\mathbf{1 1 0 - 1 2 0}$ & 6 & $19,35 \%$ \\
$\mathbf{1 2 1 - 1 3 1}$ & 5 & $16,12 \%$ \\
$\mathbf{1 3 2 - 1 4 2}$ & 6 & $19,35 \%$ \\
$\mathbf{1 4 3 - 1 5 3}$ & 4 & $12,90 \%$ \\
$\mathbf{1 5 4 - 1 6 4}$ & 3 & $9,67 \%$ \\
\hline
\end{tabular}


Dari tabel 6 di atas perhatian orangtua siswa sangat lemah sebanyak 24 orang siswa atau 9,67\%-19,35\% dan lemah sebanyak 7 orang atau $22,58 \%$.

\section{Variabel hasil belajar matematika}

Tabel 7. Data Deskriptif Hasil Belajar Matematika Kelas VII SMP Negeri 1 Baso Tahun Pelajaran 2018/2019

\begin{tabular}{cc}
\hline Data Deskripsi & Hasil \\
\hline Mean & 46,90 \\
Median & 46 \\
Skor Minimum & 32 \\
Skor Maksimum & 66 \\
Jumlah Skor Keseluruhan & 1454 \\
\hline
\end{tabular}

Tabel 8. Distribusi Hasil Belajar Matematika Siswa Kelas VII SMP Negeri 1 Baso Tahun Pelajaran 2018/2019

\begin{tabular}{ccc}
\hline Interval & Frekuensi & Persentase \\
\hline $\mathbf{3 2 - 3 7}$ & 1 & $3,22 \%$ \\
$\mathbf{3 8 - 4 3}$ & 8 & $25,80 \%$ \\
$\mathbf{4 4 - 4 9}$ & 13 & $41,93 \%$ \\
$\mathbf{5 0 - 5 5}$ & 6 & $19,35 \%$ \\
$\mathbf{5 6 - 6 1}$ & 1 & $3,22 \%$ \\
$\mathbf{6 2 - 6 7}$ & 2 & $6,45 \%$ \\
\hline
\end{tabular}

Dari tabel 8 di atas hasil belajar matematika siswa sangat lemah sebanyak 10 orang siswa atau 3,22\% - 19,35\%, lemah sebanyak 8 orang atau 25,80\% dan cukup sebanyak 13 orang siswa atau $41,93 \%$.

\section{Pengujian Prasyarat}

\section{Regresi Linier Sederhana (Parsial)}

\section{Uji Normalitas}

Uji normalitas bertujuan untuk menguji apakah dalam model regresi memiliki distribusi normal. Ada dua cara untuk melihat apakah berdistribusi normal dengan cara perhitungan manual dan uji statistik dengan menggunakan SPSS16.

\section{Uji Linieritas}

Uji linieritas dilakukan untuk melihat apakah dalam model regresi memiliki pola linier. Untuk menguji linieritas pada model penelitian menggunakan perhitungan manual dan uji statistik dengan menggunakan SPSS16.

\section{Regresi Linier Berganda (Simultan)}

\section{Uji Normalitas}

Tabel 9. Uji Normalitas Data Menggunakan SPSS 16

\begin{tabular}{|c|c|c|c|c|c|c|}
\hline & \multicolumn{6}{|c|}{ Tests of Normality } \\
\hline \multirow{4}{*}{$\begin{array}{l}\text { Motivasi } \\
\text { belajar }\end{array}$} & \multicolumn{4}{|c|}{ Kolmogorov-Smirnova } & \multicolumn{2}{|c|}{ Shapiro-Wilk } \\
\hline & Statistic & Df & Sig. & Statistic & $\mathrm{df}$ & Sig. \\
\hline & .083 & 31 & .000 & .901 & 31 & .007 \\
\hline & \multicolumn{6}{|c|}{ a. Lilliefors Significance Correction } \\
\hline & \multicolumn{6}{|c|}{ Tests of Normality } \\
\hline \multirow{4}{*}{$\begin{array}{l}\text { Perhatian } \\
\text { orangtua }\end{array}$} & \multicolumn{4}{|c|}{ Kolmogorov-Smirnova } & \multicolumn{2}{|c|}{ Shapiro-Wilk } \\
\hline & Statistic & Df & Sig. & Statistic & df & Sig. \\
\hline & .122 & 31 & $.200^{*}$ & .948 & 31 & .140 \\
\hline & \multicolumn{6}{|c|}{ a. Lilliefors Significance Correction } \\
\hline
\end{tabular}

\section{Tests of Normality}




\begin{tabular}{|c|c|c|c|c|c|c|}
\hline & Statistic & Df & Sig. & Statistic & df & Sig. \\
\hline $\begin{array}{l}\text { Hasil belajar } \\
\text { matematika }\end{array}$ & .064 & 31 & $.200^{*}$ & .950 & 31 & .160 \\
\hline
\end{tabular}

Pada tabel di atas dapat dilihat nilai sig pada kolom Kolmogorov-Smirnova ${ }^{a}$, dengan kriteria uji bahwa nilai sig $>0,05$ maka data berdistribusi normal.

\section{Uji Linieritas}

Tabel 10. Uji Linieritas Motivasi Belajar Dan Hasil Belajar Matematika

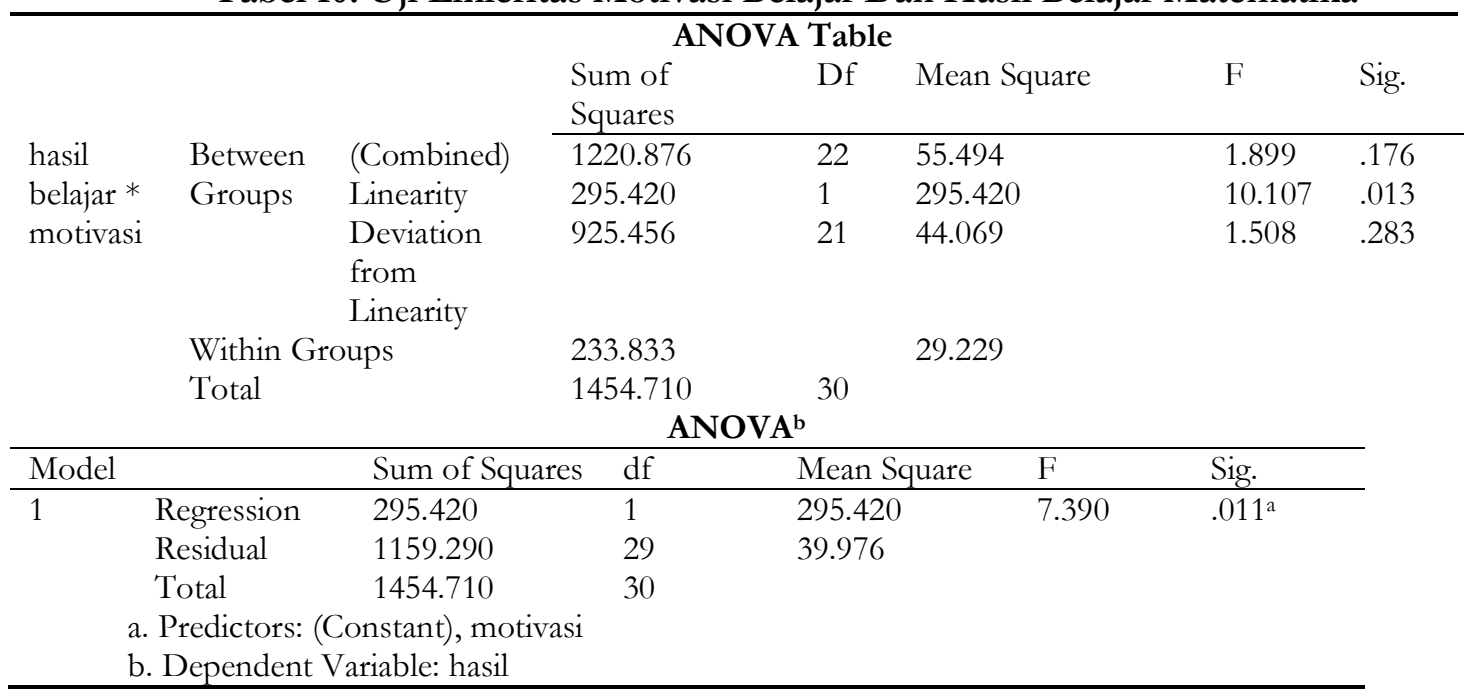

Setelah dilakukan uji linieritas maka data angket motivasi belajar dengan hasil belajar matematika yang diperoleh linier, dengan $F_{\text {hitung }}$ sebesar 7,390 dan $F_{\text {tabel }}$ sebesar 4,183 maka terpenuhi $\mathrm{F}_{\text {hitung }}>\mathrm{F}_{\text {tabel }}$.

Tabel 11. Uji Linieritas Perhatian Orangtua Dan Hasl Belajar Matematika

\begin{tabular}{|c|c|c|c|c|c|c|c|}
\hline \multicolumn{8}{|c|}{ ANOVA Table } \\
\hline \multirow{7}{*}{$\begin{array}{l}\text { hasil belajar } \\
\text { * perhatian } \\
\text { orangtua }\end{array}$} & & & $\begin{array}{l}\text { Sum of } \\
\text { Squares }\end{array}$ & Df & Mean Square & $\mathrm{F}$ & Sig. \\
\hline & Between & (Combined) & 1271.710 & 25 & 50.868 & 1.390 & .385 \\
\hline & Groups & Linearity & 237.708 & 1 & 237.708 & 6.495 & .051 \\
\hline & & $\begin{array}{l}\text { Deviation } \\
\text { from } \\
\text { Linearity }\end{array}$ & 1034.002 & 24 & 43.083 & 1.177 & .471 \\
\hline & & Within Groups & 183.000 & & 36.600 & & \\
\hline & & Total & 1454.710 & & & & \\
\hline & & & & 0 & & & \\
\hline
\end{tabular}

\begin{tabular}{|c|c|c|c|c|c|c|}
\hline \multirow{2}{*}{\multicolumn{2}{|c|}{ Model }} & \multicolumn{4}{|c|}{ ANOVA $^{b}$} & \multirow[b]{2}{*}{ Sig. } \\
\hline & & Sum of Squares & $\mathrm{df}$ & Mean Square & \multirow{4}{*}{$\begin{array}{l}F \\
5.664\end{array}$} & \\
\hline & 1 Regression & 237.708 & 1 & 237.708 & & \multirow[t]{3}{*}{$.024^{2}$} \\
\hline & Residual & 1217.002 & 29 & 41.966 & & \\
\hline & Total & 1454.710 & 30 & & & \\
\hline \multicolumn{7}{|c|}{ a. Predictors: (Constant), perhatian orangtua } \\
\hline \multicolumn{7}{|c|}{ b. Dependent Variable: hasil belajar matematika } \\
\hline
\end{tabular}

Setelah dilakukan uji linieritas maka data angket perhatian orangtua dengan hasil belajar matematika diperoleh $\mathrm{F}_{\text {hitung }}$ sebesar 5,664 dan $\mathrm{F}_{\text {tabel }}$ sebesar 4,183 maka terpenuhi $\mathrm{F}_{\text {hitung }}>\mathrm{F}_{\text {tabel. }}$

\section{Uji Multikolinieritas}

Uji multikolinieritas ini dimaksudkan untuk membuktikan atau menguji ada tidaknya hubungan yang linier diantara variabel bebas. Dalam penelitian ini ada dua variabel bebas yaitu motivasi belajar $\left(\mathrm{X}_{1}\right)$ dan perhatian orangtua $\left(\mathrm{X}_{2}\right)$. Yang digunakan mempengaruhi variabel terikat 
hasil belajar matematika. Metode pengujian yang dilakukan menggunaka uji multikolinieritas dengan melihat Variace Inflation Factor (VIF) pada model regresi.

Tabel 12. Uji Multikolinieritas

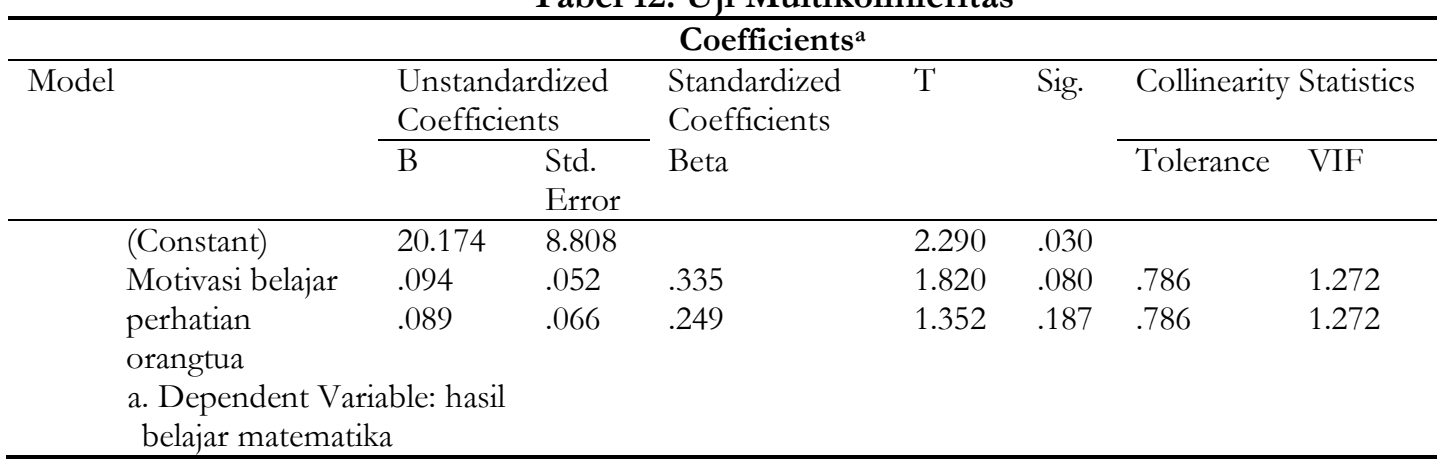

Setelah dilakukan uji multikolinieritas menggunakan SPSS 16 maka hasilnya menunjukkan tidak terjadi multikolinieritas karena nilai toleran motivasi 0,786 dan perhatian orangtua 0,786 lebih dari 0,10 . Nilai VIF menunjukkan tidak terjadi multikolieritas karena nilai VIF motivasi 1,272 dan perhatian orangtua 1,272 lebih kecil dari 10,00. Dengan demikian uji multikolinieritas terpenuhi.

\section{Uji Heterokedastisitas}

Uji heteroskedastisitas dilakukan untuk mengetahui apakah dalam sebuah model regresi terjadi ketidaksamaan varians dari residual suatu pengamatan kepengamatan lain.

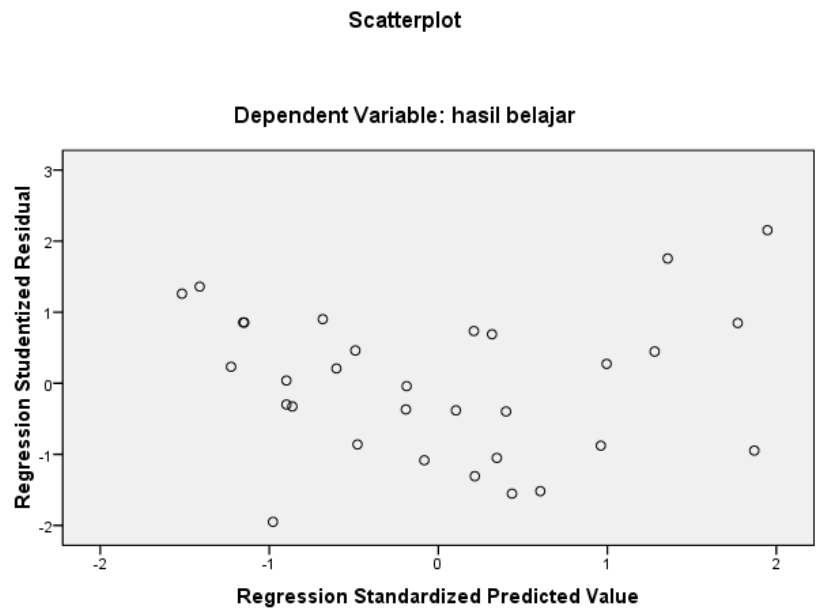

Gambar 1. Uji Heterokedastisitas

Dari gambar di atas, didapat titk penyebaran di atas sumbu $\mathrm{Y}$ dan tidak mempunyai pola yang teratur. Maka dapat disimpulkan variabel bebas di atas tidak terjadi hetoroskedastisitas.

\section{Uji Autokorelasi}

Uji autokorelasi dilakukan untuk mengetahui apakh dalam sebuah model regresi linier terdapat hubungan yang kuat baik positif maupun negatif antara data yang ada pada variabelvariabel penelitian. 
Tabel 13. Uji Autokorelasi

\begin{tabular}{|c|c|c|c|c|c|c|c|c|c|c|}
\hline \multirow{3}{*}{$\begin{array}{l}\text { Mo } \\
\text { del }\end{array}$} & \multicolumn{10}{|c|}{ Model Summary ${ }^{b}$} \\
\hline & \multirow[t]{2}{*}{$\mathrm{R}$} & \multirow{2}{*}{$\begin{array}{l}\mathrm{R} \\
\text { Square }\end{array}$} & \multirow{2}{*}{$\begin{array}{l}\text { Adjuste } \\
\text { d R } \\
\text { Square }\end{array}$} & \multirow{2}{*}{$\begin{array}{l}\text { Std. } \\
\text { Error of } \\
\text { the } \\
\text { Estimate }\end{array}$} & \multicolumn{5}{|c|}{ Change Statistics } & \multirow[b]{2}{*}{$\begin{array}{l}\text { urbin- } \\
\text { Wats } \\
\text { on }\end{array}$} \\
\hline & & & & & $\begin{array}{l}\text { R Square } \\
\text { Change }\end{array}$ & $\begin{array}{l}\text { F } \\
\text { Chan } \\
\text { ge }\end{array}$ & df1 & df2 & $\begin{array}{l}\text { Sig. F } \\
\text { Change }\end{array}$ & \\
\hline & $.502^{\mathrm{a}}$ & .252 & .198 & 6.234 & .252 & 4.714 & 2 & 28 & .017 & 1.915 \\
\hline & $\begin{array}{l}\text { a. I } \\
\text { b. D }\end{array}$ & $\begin{array}{l}\text { dictors: } \\
\text { rangtua, } \\
\text { matem }\end{array}$ & $\begin{array}{l}\text { onstant), } \mathrm{p} \\
\text { otivasi } \\
\text { riable: has } \\
\text { ka }\end{array}$ & belajar & & & & & & \\
\hline
\end{tabular}

Setelah dilakukan uji autokerelasi maka diindikasikan variabel -variabel pada penelitian ini tidak ada autokorelasi, karena nilai DW 1,915 sehinggga nilai DW statistiknya diantara -2 sampai 2 maka diindikasikan tidak ada autokorelasi.

\section{Pengujian Hipotesis}

Analisis data penelitian ditunjukan untuk (1) Menguji pengaruh motivasi belajar $\left(\mathrm{X}_{1}\right)$ terhadap hasil belajar matematika siswa $(\mathrm{Y})$. (2) Menguji pengaruh perhatian orangtua $\left(\mathrm{X}_{2}\right)$ terhadap hasil belajar matematika siswa $(\mathrm{Y})$. (3) Menguji motivasi belajar $\left(\mathrm{X}_{1}\right)$ dan perhatian orangtua $\left(\mathrm{X}_{2}\right)$ secara simultan terhadap hasil belajar matematika siswa $(\mathrm{Y})$.

Uji secara parsial bertujuan untuk mengetahui hasil belajar data regresi linier sederhana pada variabel motivasi belajar terhadap hasil belajar, dan variabel perhatian orangtua terhadap hasil belajar menggunakan SPSS 16 sebagai berikut:

Tabel 14. Uji Regersi Parsial Motivasi Belajar Terhadap Hasil Belajar Matematika

\begin{tabular}{|c|c|c|c|c|c|c|c|}
\hline \multirow{4}{*}{ Model } & & & \multicolumn{3}{|c|}{ Coefficients $^{a}$} & & \\
\hline & \multicolumn{2}{|c|}{$\begin{array}{l}\text { Unstandardized } \\
\text { Coefficients }\end{array}$} & \multirow{3}{*}{$\begin{array}{l}\text { Standardized } \\
\text { Coefficients } \\
\text { Beta }\end{array}$} & \multirow[t]{3}{*}{$\mathrm{T}$} & \multirow[t]{3}{*}{ Sig. } & \multicolumn{2}{|c|}{$\begin{array}{l}95 \% \text { Confidence Interva } \\
\text { for B }\end{array}$} \\
\hline & B & Std. & & & & Lower & Upper \\
\hline & & Error & & & & Bound & Bound \\
\hline (Constant) & 26.248 & 7.683 & & 3.416 & .002 & 10.535 & 41.960 \\
\hline Motivasi & .126 & .046 & .451 & 2.718 & .011 & .031 & .221 \\
\hline \multicolumn{8}{|c|}{$\begin{array}{l}\text { a. Dependent Variable: hasil belajar } \\
\text { matematika }\end{array}$} \\
\hline
\end{tabular}

Motivasi berpengaruh terhadap hasil belajar matematika siswa kelas VII SMP Negeri 1 Baso tahun pelajaran 2018/2019. Berdasarkan hasil perhitungan analisis variabel yang dilakukan dimana persamaan regresi sederhana adalah $\mathrm{Y}=26.248+0,126 \mathrm{X}_{1}$. Berdasarkan persamaan regresi diperoleh koefisien regresi variabel motivasi sebesar 0,126 yang berarti bahwa setiap peningkatan kemampuan motivasi sebesar satu satuan maka akan menyebabkan peningkatan hasil belajar sebesar 0,126 dan nilai $t_{\text {hitung }}$ lebih besar dari $t_{\text {tabel }}$ dengan taraf signifikan $5 \%$ yaitu 2,718 > 2,045, ini berarti terdapat pengaruh yang signifikan motivasi belajar terhadap hasil belajar matematika. koefisien determinasi adalah $\mathrm{r}^{2} .100 \%=(0,451)^{2} .100 \%=20,3401 \%$, signifikan 0,011 $<0,05$ sehingga dapat dikatakan hal ini mengandung makna bahwa motivasi belajar $\left(\mathrm{X}_{1}\right)$ secara parsial berpengaruh signifikan terhadap hasil belajar matematika (Y). hasil ini menunjukan bahwa 20,2401\% hasil belajar matematika dipengaruhi oleh motivasi belajar dan yang sebihnya dipengaruhi oleh faktor lain.

Tabel 15. Uji Regresi Parsial Perhatian Orangtua Terhadap Hasil Belajar Matematika

\begin{tabular}{|c|c|c|c|c|c|c|c|}
\hline \multirow{3}{*}{ Model } & \multicolumn{6}{|c|}{ Coefficients $^{a}$} & \\
\hline & \multicolumn{2}{|c|}{$\begin{array}{l}\text { Unstandardized } \\
\text { Coefficients }\end{array}$} & \multirow{2}{*}{$\begin{array}{l}\text { Standardized } \\
\text { Coefficients } \\
\text { Beta }\end{array}$} & \multirow[t]{2}{*}{$\mathrm{T}$} & \multirow[t]{2}{*}{ Sig. } & \multicolumn{2}{|c|}{$\begin{array}{l}95 \% \text { Confidence Interval } \\
\text { for B }\end{array}$} \\
\hline & $\mathrm{B}$ & $\begin{array}{l}\text { Std. } \\
\text { Error }\end{array}$ & & & & $\begin{array}{l}\text { Lower } \\
\text { Bound }\end{array}$ & $\begin{array}{l}\text { Upper } \\
\text { Bound }\end{array}$ \\
\hline $\begin{array}{l}\text { (Constant) } \\
\text { perhatian }\end{array}$ & $\begin{array}{l}28.482 \\
.145\end{array}$ & $\begin{array}{l}7.827 \\
.061\end{array}$ & .404 & $\begin{array}{l}3.639 \\
2.380\end{array}$ & $\begin{array}{l}.001 \\
.024\end{array}$ & $\begin{array}{l}12.475 \\
.020\end{array}$ & $\begin{array}{l}44.490 \\
.269\end{array}$ \\
\hline
\end{tabular}




orangtua
a. Dependent Variable: hasil
belajar matematika

Perhatian orangtua berpengaruh terhadap hasil belajar matematika siswa kelas VII SMP Negeri 1 Baso tahun pelajaran 2018/2019. Berdasarkan hasil perhitungan analisis variabel yang dilakukan dimana persamaan regresi sederhana adalah $\mathrm{Y}=28,482+0,145 \mathrm{X}_{2}$. Berdasarkan persamaan regresi diperoleh koefisien regresi variabel perhatian orangtua sebesar 0,145 yang berarti bahwa setiap peningkatan kemampuan perhatian orangtua sebesar satu satuan maka akan menyebabkan peningkatan hasil belajar sebesar 0,145 dan nilai $t_{\text {hitung }}$ lebih besar dari $t_{\text {tabel }}$ dengan taraf signifikan $5 \%$ yaitu 2,380 > 2045, ini berarti terdapat pengaruh yang signifikan perhatian orangtua terhadap hasil belajar matematika. koefisien determinasi adalah $\mathrm{r}^{2} \cdot 100 \%=(0,404)^{2}$ $.100 \%=16,3216 \%$, signifikan $0,024<0,05$ sehingga dapat dikatakan hal ini mengandung makna bahwa perhatian orangtua $\left(\mathrm{X}_{2}\right)$ secara parsial berpengaruh signifikan terhadap hasil belajar matematika (Y). hasil ini menunjukan bahwa 16,3216\% hasil belajar matematika dipengaruhi oleh perhatian orangtua dan yang sebihnya dipengaruhi oleh faktor lain.

Uji hipotesis regresi linier berganda bertujuan untuk mengetahui hubungan antara kedua variabel bebas terhadap variabel terikat.

Tabel 16. Hasil Uji Regresi Berganda

\begin{tabular}{|c|c|c|c|c|c|c|}
\hline \multirow{2}{*}{\multicolumn{2}{|c|}{ Model }} & \multicolumn{4}{|c|}{ Coefficients $^{\mathrm{a}}$} & \multirow{4}{*}{ Sig. } \\
\hline & & \multirow{2}{*}{\multicolumn{2}{|c|}{$\begin{array}{l}\text { Unstandardized } \\
\text { Coefficients }\end{array}$}} & \multirow{3}{*}{$\begin{array}{l}\text { Standardized } \\
\text { Coefficients } \\
\text { Beta }\end{array}$} & \multirow[t]{3}{*}{$\mathrm{T}$} & \\
\hline & & & & & & \\
\hline & & B & Std. Error & & & \\
\hline \multirow[t]{3}{*}{1} & (Constant) & 20.174 & 8.808 & & 2.290 & .030 \\
\hline & Motivasi & .094 & .052 & .335 & 1.820 & .080 \\
\hline & $\begin{array}{l}\text { perhatian } \\
\text { orangtua }\end{array}$ & .089 & .066 & .249 & 1.352 & .187 \\
\hline
\end{tabular}

a. Dependent Variable: hasil

belajar

\begin{tabular}{lllllll}
\hline \multicolumn{2}{c}{ Model } & \multicolumn{5}{c}{ ANOVA $^{\mathbf{b}}$} \\
& & $\begin{array}{l}\text { Sum of } \\
\text { Squares }\end{array}$ & Df & Mean Square & F & Sig. \\
\hline 1 & Regression & 366.421 & 2 & 183.211 & 4.714 & $.017^{\mathrm{a}}$ \\
& Residual & 1088.289 & 28 & 38.867 & & \\
& Total & 1454.710 & 30 & & &
\end{tabular}

a. Predictors: (Constant), perhatian orangtua, motivasi

b. Dependent Variable: hasil belajar

Motivasi belajar dan perhatian orangtua berpengaruh terhadap hasil belajar matematika siswa. Berdasarkan hasil perhitungan analisis variabel yang dilakukan terdapat persamaan regresi berganda $\mathrm{Y}=20,174+0,094 \mathrm{X}_{1}+0,089 \mathrm{X}_{2}$ maka koefisien regresi variabel motivasi belajar sebesar 0,094 dengan menganggap $\mathrm{X}_{2}$ sebagai konstan berarti bahwa setiap peningkatan motivasi belajar sebesar satu satuan maka akan menyebabkan peningkatan hasil belajar sebesar 0,094 dan persamaan regresi yang diperoleh koefisien regresi variabel perhatan orangtua sebesar 0,089 dengan menganggap $\mathrm{X}_{1}$ sebagai konstan berarti bahwa setiap peningkatan perhatian orangtua sebesar satu satuan maka akan menyebabkan peningkatan hasil belajar matematika sebesar 0,089 dan nilai $\mathrm{F}_{\text {hitung }}>\mathrm{F}_{\text {tabel }}$ dengan taraf signifikan $5 \%$ yaitu 4,714>3,340, ini berarti terdapat pengaruh yang signifikan motivasi belajar dan perhatian orangtua terhadap hasil belajar matematika. koefisien determinasi adalah $\mathrm{r}^{2} .100 \%=(0,502)^{2} .100 \%=25,2004 \%$ signifikan $(0,017$ $<0,05)$. Sehingga dapat dikatakan hal ini mengandung makna bahwa motivasi belajar $\left(\mathrm{X}_{1}\right)$ dan perhatian orangtua $\left(\mathrm{X}_{2}\right)$ terhadap hasil belajar matematika $(\mathrm{Y})$ hasil ini menunjukan bahwa 25,2004\% hasil belajar matematika dipengaruhi oleh motivasi belajar dan perhatian orangtua. 


\section{KESIMPULAN}

\section{Kesimpulan}

Berdasarkan pembahasan hasil penelitian diatas, peneliti menyimpulkan pertama, motivasi belajar terhadap hasil belalajar matematika siswa berpengaruh sebesar 20,2401\% dan selebihnya dipengaruhi oleh faktor selain motivasi belajar. Kedua, perhatia orangtua terhadap hasil belajar matematika berpengaruh sebesar 16,3216\% yang selebihnya dipengaruhi selain perhatian orangtua. Ketiga, motivasi belajar dan perhatian orangtua terhadap hasil belajar matematika siswa berpengaruh sebesar 25,2004\% dan yang selebihan dipengaruhi oleh selain motivasi belajar dan perhatian orangtua.

\section{Saran}

Mengingat bahwa penelitian ini hanya dilakukan dengan sejumlah indikator tentang motivasi belajar peserta didik yang terbatas, maka perlu kiranya dilakukan penelitian lanjutan tentang motivasi belajar ini dengan meninjau dari indikator motivasi belaja peserta didik yang lain

\section{REFERENSI}

B Uno, Hamzah. 2012. Teori Motivasi dan Pengukurannya. Jakarta: Bumi Aksara.

Iftikhah, Rizki. Pengarub Perhatian Orangtua Terbadap Motivasi Belajar Siswa. Jurnal Ilmiah Pendidikan Bimbingan dan Konseling.

Nashih Ulwan, Abdullah. 1999. Pendidikan Anak Dalam Islam. Jakarta: Pustaka Amani.

Riduwan. 2013. Belajar Mudah Penelitian untuk Guru-Karyawan dan Peneliti Pemula. Bandung: Alfabeta.. 